\title{
JüNAL BASTRIND足
}

\section{Nilai Religius dalam Prosesi adat Nede di Desa Sengkerang Kecamatan Praya Timur Kabupaten Lombok Tengah}

\author{
Zul Pahmi ${ }^{1}$; Norazimah Zakaria ${ }^{2}$ \\ ${ }^{1}$ Pendidikan Bahasa dan Sastra Indonesia, Universitas Mataram \\ 2 Fakulti Bahasa dan Komunikasi, Universiti Pendidikan Sultan Idris \\ Posel: molluscamanagement@gmail.com
}

\begin{abstract}
Abstrak: Penelitian ini berjudul Nilai Religius dalam Prosesi adat Nede di Desa Sengkerang Kecamatan Praya Timur Kabupaten Lombok Tengah. Adapun rumusan masalah dalam penelitian ini yaitu bagaimanakah nilai religiusitas dalam prosesi adat Nede di Desa Sengkerang Kecamatan Praya Timur Kabupaten Lombok Tengah. Peneitian ini dibuat berdasarkan tiga alasan yaitu yang pertama adanya sebuah ritual di tengah masyarakat desa Sengkerang kecamatan Praya Timur yang bernama Nede yang merupakan implementasi dari kepercayaan masyarakat terhadap kekuatan gaib atau roh-roh halus dan bendabenda keramat yang merupakan satu bentuk kearifan budaya lokal, kedua adalah terjadinya akulturasi pasca masuknya Islam, dan yang ketiga adalah banyaknya nilai-nilai agama yang dapat dipetik dalam ritual tersebut yang dapat dijadikan pelajaran dalam hidup bermasyarakat. Penelitian ini bertujuan untuk mendeskripsikan dan menganalisis nilai religiusitas yang terdapat pada tradisi Nede di Desa Sengkerang Kecamatan Praya Timur. Penelitian ini merupakan penelitian deskriptif kualitatif. Adapun tahapan dalam penelitian ini adalah yang pertama tahap reduksi data dengan menggunakan tiga metode yaitu observasi, wawancara, dan dokumentasi, tahapan yang kedua adalah tahap display data dan terakhir adalah penyajian data. Adapun teori yang digunakan untuk menganalisis data dalam kajian ini adalah teori kebudayaan. Hasil penelitian menunjukkan bahwa dalam prosesi adat Nede terdapat banyak nilai agama yang terangkum dalam tiga katagori yaitu nilai ibadah, nilai akidah dan akhlak.
\end{abstract}

Kata Kunci: Nilai Religius, Adat, Nede.

Religious values in the traditional procession of Nede in Sengkerang Village, Praya Timur District, Central Lombok Regency.

Abstract. This study is entitled Religious values in the traditional procession of Nede in Sengkerang Village, Praya Timur District, Central Lombok Regency. The formulation of the problem in this study is how the value of religiosity in the traditional Nede procession in Sengkerang Village, Praya Timur District, Central Lombok Regency. This research was made based on three reasons, namely the existence of a ritual in the community of Sengkerang village, Praya Timur sub-district called Nede, which is an implementation of the community's belief in supernatural powers or spirits and sacred objects which are a form of local cultural wisdom, secondly, the occurrence of acculturation after the entry of Islam and the third is the number of religious values that can be learned in these rituals which can be used as lessons in social life. This study aims to describe and analyze the value of religiosity contained in the Nede tradition in Sengkerang Village, Praya Timur District. This research is a qualitative descriptive study. The stages in this research are the first stage of data reduction using three methods, namely observation, interviews, and documentation, the second stage is the data display and the last is the presentation of the data. The theory to analyze the data in this study is the theory of culture. The results showed that in the traditional Nede procession there were many religious values summarized in three categories, namely the value of worship, the value of Akidah and morals.

Keywords: Religious Values, Customs, Nede. 


\section{PENDAHULUAN}

Kepribadian suatu bangsa di antaranya terletak pada kebudayaan, tradisi, dan adat istiadat yang ada di dalamnya. Kebudayaan merupakan satu keseluruhan dari sistem, gagasan, perasaan, dan karya suatu kelompok tertentu sebagai hak milik sebagai hasil dari proses belajar (Koentjaraningrat 2015), sedangkan tradisi merupakan suatu kebiasaan yang dilakukan secara rutin dan biasanya bersifat turun-temurun dan tetap dilestarikan di tengahtengah masyarakat (Kamus Bahasa Indonesia untuk Pelajar, 2011). Berdasarkan penjelasan tersebut dapat diketahui bahwa kebudayaan merupakan suatu produk yang dihasilkan oleh masyarakat tertentu melalui proses belajar. Oleh karena itu, kebudayaan dan tradisi yang dimiliki oleh suatu bangsa dapat menjadi penunjuk identitas dan kepribadian bangsa tersebut.

Setiap daerah tentu memiliki adat-istiadat tersendiri yang menjadikannya berbeda dengan masyarakat lainnya dan setiap tradisi tentu memiliki unsur simbolis yang dapat dilihat dari bentuk-bentuk ritualnya. Hal ini penting untuk memberikan pengaruh terhadap pemikiran baik secara individu maupun kelompok sehingga lebih sempurna dalam kehidupan. Hal inilah yang melandasi terbentuknya kearifan budaya (Pahmi, 2020). Di tengah-tengah masyarakat desa Sengkerang kabupaten Lombok Tengah terdapat sebuah ritual kebudayaan yang dilestarikan sampai sekarang. Ritual tersebut merupakan kegiatan rutin yang dilakukan oleh masyarakat dalam rangka memanjatkan syukur dengan cara berdoa di salah satu makam yang dianggap keramat. Tradisi yang disebut sebagai Nede ini dilatarbelakangi dari kepercayaan masyarakat desa Sengkerang kecamatan Praya Timur terhadap roh-roh atau kekuatan magis yang ada pada suatu benda dan tempat yang dianggap keramat. Namun dengan masuknya pemahaman Islam ke tanah Lombok, tradisi Nede ini mulai mengalami berbagai perubahan pada tatanan praktis.

Tradisi Nede ini pada awalnya dilakukan dengan cara membawa sesaji serta memohon pada makam yang dianggap keramat. Akan tetapi, pada praktiknya, setelah masyarakat memiliki pemahaman tentang akidah islamiah kegiatan tersebut mengalami pergeseran menjadi ziarah makam guna memberikan doa untuk arwah yang sudah meninggal. Kegiatan Nede ini diisi pula dengan berbagai kegiatan lain seperti membawa Dulang Tinggi yang berisi biji-bijian, umbi-umbian, dan hasil bumi lainnya ke Makam Mbung Puntiq sebagai perwujudan rasa syukur kepada Tuhan karena diberikan hasil bumi yang melimpah. Selanjutnya digelar zikir dan doa kemudian diakhiri dengan makan bersama dari bahan makanan yang dibawa pada Dulang Tinggi tersebut sebagai bentuk perwujudan rasa syukur dan rasa suka cita.

Problematika yang kerap terjadi di tengah masyarakat adalah adanya hubungan yang terlihat kurang harmonis antara masyarakat adat dengan agama. Terjadi disharmonisasi pada tatanan prinsip yang berdampak adanya hubungan yang tidak harmonis terutama pada prinsip-prinsip beragama. Banyak terjadi konflik karena saling menyalahkan antara satu dan yang lainnya karena anggapan bahwa masyarakat adat mengamalkan beberapa ritual yang tidak sesuai dengan ajaran agama. Perihal ini yang melatarbelakangi ketertarikan peneliti untuk meneliti ritual Nede secara mendalam untuk menemukan hubungan antara nilai-nilai agama dan adat-istiadat sehingga tidak terjadi kesalahpahaman. Pengkajian terhadap ritual ini untuk menemukan salah satu hubungan antara beberapa ritual pada proses Nede yang diamalkan hingga saat ini di tengah-tengah masyarakat desa Sengkerang kecamatan Praya Timur dengan nilai-nilai agama yang kemudian dapat disinergikan sehingga memberikan pemahaman kepada masyarakat bahwa antara adat istiadat dan agama masih bisa berjalan secara harmonis.

Berdasarkan pemaparan di atas, peneliti memilih prosesi adat Nede sebagai objek dalam penelitian ini karena dalam prosesi adat Nede terdapat banyak nilai agama yang dapat diambil sebagai falsafah dan pelajaran dalam kehidupan bermasyarakat. Kedua, ritual ini merupakan sebuah kearifan lokal yang masih dipelihara oleh masyarakat desa Sengkerang kecamatan 
Praya Timur hingga saat ini. Ketiga, belum ada penelitian yang mengkaji tentang ritual Nede sebagai objek kajian sehingga perlu adanya penelitian yang lebih mendalam tentang ritual Nede sehingga kearifan lokal ini dapat dilestarikan.

Beberapa penelitian yang sebelumnya pernah diteliti oleh beberapa peneliti sangatlah relevan. Wardani (2017) dalam penelitiannya menemukan tata cara pelaksanaan tradisi perkawinan adat Jawa Desa Cerme dengan urut. Selain itu, Wardani juga menemukan alatalat yang digunakan pada tradisi perkawinan adat Jawa Desa Cerme. Nilai religus yang ditemukan pada tradisi tersebut adalah memohon keselamatan serta berkah terhadap Tuhan Yang Maha Esa. Dalam penelitian Wardani ini terdapat persamaan dengan penelitian yang akan dilakukan yaitu sama-sama meneliti nilai-nilai agama dalam sebuah ritual masyarakat.

Kedua adalah penelitian oleh Yuniarti (2013). Pada penelitian tersebut Yuniarti berusaha mengkaji apa saja perlengkapan dan hal apa saja yang melatarbelakangi, tatacara pelaksanaan, serta nilai yang terkandung pada Temu Manten sebagai rangkaian upacara adat perkawinan di Jawa. Hasil dari penelitian ini adalah ditemukannya hakikat dari tradisi Temu Manten, beberapa prosesi dari tradisi, perlengkapan yang digunakan, fungsi dan makna, dan nilai Agama yang ada di dalamnya. Berdasarkan keterangan tersebut ditemukan perbedaan penelitian oleh Yuniarti ini dengan penelitian yang akan dilakukan ialah pada objek dan lokasi penelitian. Adapun persamaannya adalah sama-sama mencari nilai agama dalam sebuah tradisi.

Penelitian ketiga adalah penelitian oleh Wulandari (2016). Penelitian tersebut berusaha mengkaji tata cara pelaksanaan dan nilai budaya Islam yang terdapat pada tradisi ziarah kubur di kecamatan Tanjung Batu. Wulandari menemukan delapan tata cara pelaksanaan ziarah kubur di kecamatan Tanjung Batu, ia juga menemukan nilai-nilai budaya Islam yang terkandung dalam tradisi tersebut. Berdasarkan keterangan tersebut diketahui bahwa terdapat beberapa perbedaan penelitian ini dengan penelitian yang akan di lakukan yaitu objek dan lokasi penelitian. Adapun persamaan penelitian Wulandari dengan penelitian ini adalah sama-sama meneliti nilai agama yang ada pada tradisi ziarah kubur.

Dari penelitian-penelitian di atas dapat diambil kesimpulan bahwa penelitian yang akan dilakukan adalah penelitian yang serupa, tetapi objek dan lokasi penelitian berbeda. Penelitian ini sama-sama meneliti tentang nilai-nilai dalam sebuah tradisi masyarakat.

\section{LANDASAN TEORI}

\section{Kebudayaan}

Secara antropologi, istilah kebudayaan dapat didefinisikan sebagai keseluruhan dari sistem gagasan, hasil karya, dan tindakan manusia dalam bermasyarakat yang dijadikan sebagai milik diri dengan belajar (Koenjaraningrat, 2015: 144). Dalam (Budiwati, 2004) disebutkan bahwa kebudayaan adalah sebuah kebiasaan, kepribadian, pengembangan tekhnologi, dan gagasan di tengah masyarakat yang menjadi dasar bagi pembentukan hubungan-hubungan sosial.

C. Kluckhon (1953) menjelaskan bahwa terdapat tujuh unsur dalam kebudayaan, 1) sistem bahasa, 2) pengetahuan, 3) organisasi sosial, 4) peralatan hidup, 5) sumber pencaharian, 6) agama, dan 7) kesenian. Ketujuh unsur tersebut diperoleh oleh manusia melalui proses internalisasi, sosialisasi, dan enkulturasi.

Dalam perkembangannya, kebudayaan mengalami beberapa proses perubahan, seperti evolusi, difusi, dan akulturasi. Evolusi merupakan bentuk perkembangan kebudayaan dari kebudayaan yang relatif rendah menuju kebudayaan yang lebih tinggi. Difusi adalah suatu bentuk perkembangan dalam sebuah kebudayaan sebagai dampak dari adanya masyarakat pendatang. Akulturasi merupakan persentuhan antara dua buah kebudayaan secara langsung yang menyebabkan munculnya bentuk baru dalam kebudayaan (Budiwati, 2004: 2.19 - 2.20). 


\section{Folklor}

Secara etimologi, kata "folklor" adalah kata majemuk yang terdiri atas dua kata dasar yaitu folk dan lore serta bentuk pengindonesiaan kata dalam bahasa Inggris yaitu folklore. Alan Dundes berpendapat bahwa Folk merupakan definisi dari sekelompok orang dengan ciri fisik, sosial, dan kebudayaan sehingga menjadi acuan untuk membedakannya dari kelompok yang lain. Ciri tersebut dapat berupa kesamaan pada warna kulit, bentuk rambut, mata pencaharian, bahasa, taraf pendidikan, dan agama (Dundes dalam Danandjaya, 1986). Lore merupakan satu bentuk kebiasaan sekelompok orang yang diwariskan baik secara lisan maupun melalui contoh gerak isyarat atau alat pembantu pengingat. Dengan demikian, secara keseluruhan istilah folklore ialah keseluruhan dari kebudayaan suatu masyarakat yang diwariskan dari genersi ke generasi secara tradisional dalam versi yang berbeda, baik itu secara lisan maupun contoh yang disertai dengan gerak isyarat.

Untuk membedakan folklor dari kebudayaan yang lain, kita harus mengidentifikasi ciri utamnya. Menurut Danandjaya terdapat beberapa ciri utama foklor yang dapat di lihat diantaranya adalah diturunkan secara lisan, melalui tuturan dari mulut ke mulut dari satu generasi ke generasi berikutnya. Selanjutnya adalah bersifat tradisional. Arti dari sifat tradisional ini adalah penyebarannya terjadi di antara masyarakat tertentu dalam kurun waktu yang relatif lama (terjadi secara alami), ada dalam varian yang berbeda. Hal ini terjadi akibat penyebarannya yang secara oral dari mulut ke mulut, secara mudah, folklor dapat mengalami perubahan. Walaupun demikian, perubahannya hanya terjadi pada bagian luarnya saja, tetapi bentuk-bentuk dasarnya akan tetap bertahan. Pada proses penciptaannya bersifat anonim atau tidak diketahui penciptanya. Folklor juga memiliki bentuk yang terpola, memiliki kegunaan dalam masyarakat, memiliki logika tersendiri yang berlainan dengan logika umum (bersifat pralogis), milik bersama dalam suatu komunal, seringkali terlihat kasar dan dan spontan (Danandjaya, 1986).

Brunvand telah membagi folklor kedalam tiga kelompok besar berdasarkan pada tipenya, di antaranya adalah folklor lisan (mentifact), folklor sebagian lisan (sociofact), dan terakhir adalah folklor bukan lisan (artifacts). Bentuk-bentuk yang tergolong dalam kelompok folklor lisan adalah bahasa masyarakat, ungkapan-ungkapat yang bersifat tradisional, pertanyaan tradisional, puisi rakyat, prosa, serta nyanyian masyarakat. Bentuk yang tergolong ke dalam folklor sebagian lisan ialah kepercayaan-kepercayaan yang ada dalam masyarakat, teater rakyat, permainan rakyat, adat dan istiadat, pesta rakyat, tari rakya, upacara, dan lain-lain. Selanjutnya, bentuk-bentuk folklor nonlisan adalah kerajinan tangan, pakaian dan perhiasan, makanan dan minuman, arsitektur, gerak isyarat, dan musik dan bunyi isyarat (Brunvand dalam Rafiek, 2012).

Keseluruhan jenis folklor tersebut memiliki berbagai macam kegunaan penting dalam proses kehidupan manusia. Bascom berpendapat mengenai fungsi folklor dalam kehidupan manusia, terdapat empat fungsi yang dapat dijabarkan yaitu l) sistem cerminan atau proyeksi dari angan-angan suatu masyarakat, 2) alat pengesahan pranata dan lembaga kebudayaan, 3) alat pendidikan, dan 4) alat pengontrol agar norma-norma di tengah masyarakat dapat dipatuhi oleh anggota kolektifnya. Selain itu, Dundes juga menyebutkan bahwa folklor memiliki fungsi yang lain, seperti 1) untuk mempererat rasa solidaritas masyarakat, 2) sebagai alat pembenaran suatu masyarakat, 3) sebagai bentuk arahan terhadap masyarakat supaya dapat mencela orang lain, 4) alat untuk memberi protesan terhadap ketidakadilan, dan 5) sebagai media hiburan (Dalam Endraswara, 2013).

Nilai.

Menurut Kamus Bahasa Indonesia untuk Pelajar, nilai dapat berarti 1) harga (dalam arti taksiran harga), 2) harga uang, 3) angka kepandaian, 4) banyak sedikitnya isi, kadar, serta mutu, dan 5) sifat-sifat (hal-hal) yang penting atau berguna bagi kemanusiaan (2011). Berdasarkan pengertian tersebut diketahui bahwa nilai merupakan tolak ukur yang digunakan manusia untuk 
menentukan mutu, kuwalitas, dan harga dari suatu hal, benda, dan sikap dari seseorang atau sekelompok orang.

Steeman menyatakan bahwa nilai merupakan sesuatu yang dijunjung tinggi, yang menjiwai tindakan seseorang (Sjarkawi, 2008). Jadi, nilai bukan saja berarti tolak ukur seseorang atau sekelompok orang terhadap mutu, kualitas, dan harga dari suatu hal, benda, dan sikap orang lain, tetapi nilai juga merupakan sesuatu yang dijunjung, yang mewarnai, dan menjadi pengarah, pengendali serta penentu perilaku seseorang.

Penelitian ini memiliki dua nilai yang akan dikaji dalam tradisi Nede Desa Sengkerang Kecamatan Praya Timur Lombok Tengah. Dua nilai tersebut adalah nilai religius dan nilai budaya.

\section{Nilai Religius.}

Seperti telah dijelaskan di atas bahwa nilai merupakan tolok ukur seseorang atau sekelompok orang terhadap mutu, kualitas, dan harga suatu hal, benda, dan sikap orang lain yang dijunjung tinggi dan yang mewarnai, mengarahkan, mengendalikan, serta menentukan sikap dari seseorang atau sekelompok orang tersebut.

Religius merupakan kata dari bahasa Latin yaitu religare yang memiliki makna mengikat atau menambatkan. Selain itu, religius juga terdapat dalam bahasa Inggris yaitu religion yang memiliki arti agama (Asmuni, 1997). Dengan demikian, dapat dimaknai bahwa religius merupakan perilaku yang taat dalam menjalankan ajaran-ajaran dalam agama yang dianut serta memiliki sikap toleransi terhadap agama lain (Fadlillah dan Khorida, 2013). Oleh karena itu, dapat ditarik satu kesimpulan bahwa nilai religius merupakan nilai-nilai yang bersumber dari keyakinan terhadap tuhan yang tertanam dalam diri seseorang (Sjarkawi, 2008). Dengan demikian, nilai religius merupakan tolok ukur yang dilandaskan pada perilaku, sikap serta kepatuhan seseorang atau komunal dalam menjalankan ajaran agamanya.

Zuhairini menjelaskan bahwa terdapat tiga dasar-dasar dalam agama Islam di antaranya adalah akidah, syariah, dan akhlak (Zuhairini, 1997). Pendapat tersebut selaras dengan pendapat Yusuf Al-Qardhawy yang menyebutkan bahwa dimensi-dimensi atau pokok-pokok dalam ajaran agama Islam secara garis besar dibagi menjadi 3, di antaranya adalah akidah, ibadah, dan akhlak (Yusuf Al Qardhawy, 1997).

\section{Akidah.}

Ajaran mengenai keimanan kepada keesaan Tuhan disebut sebagai akidah, akidah juga sering disamakan dengan keimanan yang menunjukkan tingkatan keyakinan terhadap kebenaran ajaran agama (Nata, 2004). Hassan Al-Banna (dalam Sukarta, 2014) menjelaskan bahwa bahwa al-Aqa'id merupakan bentuk jamak dari kata akidah, yaitu beberapa perkara yang wajib diyakini kebenarannya oleh hati (mu) secara mutlak yang mendatangkan ketentraman jiwa, menjadi sebuah keyakinan yang tidak tercampuri sedikitpun oleh keraguan. Adapun beberapa aspek daripada akidah yang ada dalam ajaran Islam di antaranya adalah: 1) keyakinan tentang adanya Allah beserta dengan segala sifat-Nya, 2) keyakinan tentang adanya malaikat beserta dengan sifat dan tugas-tugasnya, 3) keyakinan tentang Firman-Firman Allah SWT yang ada dalam kitab-kitab yang diturunkan kepada para Rasul, 4) keyakinan tentang kerasulan utusan-Nya dengan cara mematuhi apa yang diajarakannya serta meneladani akhlaknya, 5) keyakinan tentang adanya hari akhir, dan 6) keyakinan tentang qada' dan qadar Allah SWT.

Selain keyakinan terhadap keenam hal pokok tersebut, aspek akidah juga meliputi keyakinan terhadap perkara yang dituliskan dalam Alquran seperti kepercayaan tentang adanya kebangkitan dari alam kubur, penghisaban amal, keyakinan tentang adanya surga dan neraka, keyakinan akan janji Allah pasti benar, hukum Allah serta perkara-perkara yang diberitakan dalam al-Qur'an. 
2. Ibadah.

Secara Bahasa, Ibadah bermakna tunduk, turut, ikut, taat, dan doa (Daud, 2002). Ahmadi dan Salimi (1994) menjelaskan bahwa ibadah merupakan sebuah petunjuk atau tata cara pengaturan perilaku hidup manusia guna mencapai keridaan Allah SWT. Adapun pokok-pokok ibadah yang terdapat dalam Islam dijabarkan melalui Hadist Nabi SAW di bawah ini

"Islam dibangun atas lima perkara, yaitu mengakui bahwa sesungguhnya tidak ada Tuhan selain Allah dan Nabi Muhammad sebagai utusan Allah, mendirikan sholat, mengeluarkan zakat, mengerjakan puasa ramadhan, dan menunaikan haji bagi yang mampu". (HR. Muslim).

3. Akhlak.

Secara etimologi, kata akhlak berasal dari bahasa Arab akhlaqun dan merupakan bentuk jamak dari kata khuluqun yang diartikan budi pekerti, perangai, tingkah laku atau tabiat, kebiasaan, tatakrama, sopan santun, adab, dan tindakan (Muhirdan, 2015:1). Adapun sumber akhlak dalam Islam adalah Al-Qur'an dan Sunnah Nabi Muhammad SAW, bukan penilaian manusia. Sebab bila akhlak dilandasi dengan ukuran penilaian manusia, akan menimbulkan perbedaan.

Jika dilihat dari sisi hubungannya, kajian mengenai ruang lingkup akhlak ada empat yaitu: akhlak manusia kepada sang khaliq (Allah), akhlak manusia dengan sesama manusia, akhlak dengan diri sendiri, dan akhlak manusia dengan lingkungannya.

\section{METODOLOGI}

Penelitian ini adalah penelitian deskriptif-kualitatif. Tahapan dalam penelitian ini adalah yang pertama tahap reduksi atau pengumpulan data. Pada tahap ini metode yang digunakan ada tiga yaitu metode observasi, metode wawancara, dan metode dokumentasi, tahapan yang kedua adalah tahap display data dan terakhir adalah penyajian data. Penelitian ini sangat sesuai dikaji dengan menggunakan teori kebudayaan.

\section{PEMBAHASAN}

Nede merupakan kegiatan, aktivitas, ritual budaya sekaligus upacara keagamaan yang dilakukan oleh masyarakat desa Sengkerang kecamatan Praya Timur kabupaten Lombok Tengah. Kegiatan Nede dilakukan sebagai bentuk implementasi rasa syukur, harapan, dan doa masyarakat terhadap Tuhan Yang Maha Esa. Masyarakat meyakini bahwa beberapa tempat peninggalan leluhur seperti makam, petilasan (persinggahan), dan lain sebagainya memiliki kekuatan spiritual yang mengaturnya. Oleh karena itu, kegiatan Nede masih dilestarikan oleh masyarakat Desa Sengkerang sampai hari ini. Secara etimologi Nede berarti makan, pengertian tersebut kemudian dalam prosesnya di kecamatan Praya Timur beralih menjadi acara yang kompleks dengan berbagai ritual.

Prosesi Nede diawali dengan penentuan hari dan tanggal pelaksanaan yang ditentukan oleh Mangku Makam (Makam Embung Puntiq), setelah itu dilanjutkan dengan musyawarah antar pemangku di beberapa dusun yang akan ikut melaksanakan ritual tersebut. Kemudian diadakan persiapan berupa alat dan beberapa piranti yang akan dibawa pada saat pelaksanaan prosesi adat, Pepaosan (membaca hikayat dalam daun Lontar) dilaksanakan sebagai rangkaian acara pada malam sebelum hari pelaksanaan ritual Nede dan setelah itu masyarakat akan berjalan kaki menuju Makam Embung Puntiq dengan menggunakan Praje (Arak-Arakan berbentuk singa atau kuda) dengan diiringi Gamelan. Pada acara Nede di makam Mbung Puntiq, sebelum masuk ke area makam, mangku akan mengarahkan masyarakat dan Praje untuk mengelilingi makam berlawanan arah jarum jam sebanyak sembilan kali. Setelah itu, mangku 
membaca doa untuk membuka pintu gerbang pertama dan pintu kedua Makam, beberapa orang kemudian di tugaskan untuk mengambil air di Lingkoq (Sumur) emas yang berada di sebelah kanan makam untuk digunakan airnya sebagai ritual. Selanjutnya Mangku bersama beberapa orang yang sudah ditentukan akan melakukan ritual dan doa di dalam makam dengan menaruh sesajen. Kegiatan selanjutnya diisi dengan zikir dan do'a serta makanan bersama sebagai bentuk persembahan terhadap kekuatan yang bersifat spiritual. Hal itu menunjukkan bahwa ritual Nede membentuk kepercayaan dan keyakinan pada kekuatan atau kuasa di atas manusia dan alam.

Nilai religius ialah nilai-nilai yang berasal dari kepercayaan atau keyakinan terhadap Tuhan yang ada dalam diri seseorang (Sjarkawi, 2008). Oleh karena itu, nilai ini merupakan salah satu tolok ukur yang didasarkan pada sikap, perilaku, dan kepatuhan seseorang atau sekelompok orang dalam menjalankan ibadah serta ajaran-ajaran agama yang dianutnya.

\section{Akidah}

Akidah Islam merupakan salah satu pondasi dasar yang sangat berpengaruh terhadap gairah atau semangat beramal seseorang. Tidak bisa dipungkiri bahwa pembahasan tentang definisi akidah akan mengarah pula terhadap beberapa istilah lain yang semakna dengan akidah yaitu iman dan tauhid dan yang semakna dengan ilmu tauhid yaitu ushuluddin, ilmu kalam, dan fikih akbar. Setelah dilakukan analisis terhadap ritual ini ditemukan beberapa aspek akidah yang terdapat dalam Islam yang terkandung dalam ritual Nede antara lain sebagai berikut.

\section{Keyakinan tentang Adanya Allah SWT}

Dalam setiap proses ritual Nede, keyakianan tentang adanya Allah SWT beserta dengan sifat-Nya ialah hal yang paling utama. Hal ini tergambarkan melalui beberapa tanda yang dapat kita temukan. Salah satu yang paling terlihat adalah setiap mengawali ritual selalu dimulai dengan menyebut nama Allah seperti bacaan-bacaan Bismillahirrohmanirrahim. Hal ini menunjukkan bahwa masyarakat suku Sasak yang tercermin dalam konteks kehidupan yang kental akan kebudayaan tidaklah lepas dari prinsip-prinsip dan nilai agama dalam setiap sendi-sendi ritual yang dijalaninya.

Ritual yang diyakini dan dijalani oleh masyarakat Sasak dalam kegiatan budaya yang tertuang dalam kegiatan Nede ini tentunya juga tidak menyampingkan keyakinan kepada Allah SWT. Hal ini tercermin dalam seluruh kegiatan yang dilakukan dalam proses Nede selalu diawali dengan bacaan Bismillahirrohmanirrahim yang dalam bahasa Arab yang artinya, dengan nama Allah yang maha pemurah lagi maha penyayang. Tauhid ini sangat kuat mengakar dalam masyarakat bahwa keyakinan terhadap Allah berada di atas segalanya, segala yang dilakukan tidak terlepas dari dan atas izin dari Allah SWT.

Dalam sebuah hadits Imam Al-Baihaqy, Imam Nasai, dan Imam Ahmad bahwa ziarah makam atau kubur adalah perkara mengingat bahwa ada kemtian setelah kehidupan, mengingatkan kita bahwa ada kehidupan lain setelah adanya kehidupan dunia.

\section{"Sebab ziarah kubur itu akan mengingatkan pada hari akhirat."}

Dari hadis tersebut terdapat manfaat dari ziarah kubur sebagai media pengingat terhadap adanya hari setelah kehidupan dunia yaitu hari akhirat. Sebagai seorang muslim tentu saja kita perlu untuk mengingat tentang kematian untuk menghindarkan kita dari kebahagiaan dunia semata dan kita dapat mempersiapkan kematian dengan sebaik-baiknya kematian. Selain itu, ziarah kubur juga merupakan salah satu cara kita untuk mendoakan orang yang sudah meninggal dunia. 


\section{Ibadah}

Ibadah secara arti bahasa bermakna ketaatan, ketundukan, turut, ikut dan doa (Daud, 2002). Adapun pokok-pokok yang termasuk dalam ibadah sudah terumuskan dalam rukun Islam yaitu adanya pengakuan dalam diri bahwa sesungguhnya tidak ada Tuhan selain Allah dan Nabi Muhammad merupakan utusan Allah. Adanya tekat dalam diri untuk tetap mendirikan sholat, mengeluarkan zakat, mengerjakan puasa di bulan Ramadhan, serta menunaikan haji bagi yang mampu sebagai upaya penyempurnaan ibadah kepada Allah SWT.

Dalam proses Nede dapat ditemukan beberapa bacaan yang menunjukkan bahwa keyakinan kepada Allah SWT dan Rasulullah SAW sangatlah kuat, terbukti di setiap do'a yang dibacakan selalu diawali syahadat, salah satu contohnya adalah

“Bismillahirrahmanirrahim..

Tabeq mas ilir bayu suke badan suci kang sempurne, sesempurne rage Baginda Muhammad Rasulullah. Nede berkat kalimah Lailahailullah Muhammad Rasulullah".

Dengan menyebut nama Allah yang maha pengasih lagi maha penyayang, permisi, mohon izin, hamba menyucikan badan di air suci ini, agar badan saya sempurna sesempurna badan baginda rasullallah SAW. Nede berkat kalimat tiada tuhan selain Allah dan Muhammad rasullallah.

Pada proses ritual yang bernilai ibadah yang dijalani oleh masyarakat di makam Mbung Puntiq adalah zikir dan doa. Kegiatan zikir dan doa ini merupakan salah satu wujud mengingat Tuhan Yang Maha Esa. Di bawah ini terdapat salah satu hadis yang diriwayatkan oleh AtTirmidzi no 2969, Rasulullah SAW bersabda:

\section{الأَُعَاعُ مُنُْ الْعِبَادَةِة}

Artinya: "doa itu merupakan inti dari ibadah"

Oleh karena itu, zikir dan doa beserta penyebutan nama Tuhan dan syahadat di setiap memulai prosesi adat Nede ini merupakan salah bukti yang menunjukkan bahwa ritual ini sangat kental dengan nilai-nilai agama.

\section{Akhlak}

Akhlak berasal dari bahasa Arab, yaitu khuluqun, yang berarti budi pekerti, meskipun kata akhlak berasal dari bahasa arab, namun kata akhlak tidak banya dijumpai dalam AlQur'an. Sebagian besar kata akhlak dijumpai dalam hadis. Satu-satu kata semakna yang dijumpai dalam Al-Qur'an adalah bentuk tunggal yaitu khuluqun yang tercantum dalam surat Al-Qalam (68:4).

\section{"Sesungguhnya engkau Muhammad berada di atas budi pekerti yang agung"}

Akhlak itu sendiri memiliki sifat sebagai penyempurna bagi kedua amal di atas yang mengajarkan tentang tata cara pergaulan hidup manusia. Masyarakat Sasak di pulau Lombok sangat mengagungkan akhlak atau perangai, baik akhlah kepada diri sendiri, akhlak dalam kehidupan bermasyarakat, akhlah kepada Allah SWT, dan akhlak kepada alam. Dalam proses kebudayaan yang mengakar dalam masyarakat tentunya terdapat simbol-simbol yang terselip di dalamnya yang penuh dengan nilai-nilai kehidupan yang dapat dijadikan panduan hidup. Prosesi adat Nede tentu tidak lepas dari nilai-nilai yang menitikberatkan keutamaan berakhlak baik, nilai-nilai tersebut dapat kita lihat dari bagimana hubungan kita dengan Allah, hubungan kita dengan diri sendiri, hubungan dengan keluarga, hubungan dengan masyarakat dan 
hubungan kita dengan alam, tentu dalam menjaga hubungan yang baik tersebut harus ditunjang dengan akhlak atau tata krama yang baik pula.

\section{Hubungan dengan Allah}

Ritual Nede berangkat dari pijakan beragama seperti bersyukur. Masyarakat melakukan Nede sebagai bentuk rasa syukur kepada Allah SWT karena telah dikarunia rizki yang melimpah serta wujud rasa syukur atas datangnya musim hujan sebagai penanda akan datangnya musim menanam padi yang merupakan sumber utama penghasilan masyarakat.

Nede memiliki makna bersyukur dengan rezeki yang Allah limpahkan. Oleh sebab itu, masyarakat menjadikan Nede ini sebagai ajang untuk bersedekah sebagai bentuk rasa syukur dengan membawa sebagian hartanya dalam bentuk makanan untuk dimakan bersama dengan masyarakat lainnya.

Kegiatan Nede ini juga tidak lepas dari kegiatan memohon atau berdoa, berdoa kepada Allah atas kesehatan, dilapangkan rezeki, dan dijauhkan dari segala penyakit. Hal ini menunjukkan bahwa masyarakat Sasak meyakini bahwa Allah adalah tempat memohon petunjuk di setiap melakukan sebuah kegiatan. Hanya Allah tempat berdoa, walaupun di makam tempat berdoa bukan berarti mereka meminta kepada makam, namun kepada Allah SWT.

\section{Hubungan dengan diri sendiri}

Rasa syukur, dengan bersedekah pada proses Nede dalam masyarakat Sengkereang, pada prinsipnya bukan hanya berkaitan dengan hubungan dengan sesama, namun juga berkaitan erat dengan keyakinan beragama. Tidak hanya kebutuhan secara fisik seperti makan dan minum atau kebutuhan secara sosial seperti silaturrahmi dan berkumpul, namun juga kebutuhan batin yang seharusnya selalu dipupuk dengan nilai-nilai yang diajarkan oleh agama seperti sifat qanaah, bersyukur, silaturrahmi dan berdoa merupakan kebutuhan batin secara agama.

Manusia sebagai insan yang tak terlepas dari penyakit hati seperti iri hati, dengki, sombong, dan lain-lain harus dilebur melalui proses silaturahmi, bersyukur, dan berdoa seperti yang dilakukan dalam proses Nede ini.

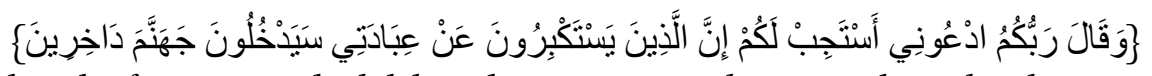

"Dan Rabbmu berfirman: "Berdoalah kepada-Ku, niscaya akan Kuperkenankan bagimu. Sesungguhnya orang-orang yang menyombongkan diri dari menyembah-Ku akan masuk neraka Jahanam dalam keadaan hina dina." (QS. Al Mukmin: 60).

Ayat ini memberikan pemahaman kepada kita bahwa berdoa merupakan suatu tindakan memohon yang bernilai ibadah dan meninggalkan berdoa merupakan sebuah sikap yang sombong, tidak ada kesombongan yang lebih buruk daripada kesombongan seperti ini, kesombongan ini adalah bagian dari kekufuran terhadap nikmat Allah Ta'ala. (Lihat kitab Tuhfat Adz Dzakirin, karya Asy Syaukani). Sebagian manusia terlalu sombong, tidak mau berdoa, seakan ia bisa menghasilkan sesuatu tanpa pertolongan dari Allah Ta'ala. Hal inilah yang merupakan bentuk hubungan manusia dengan diri sendiri, di mana manusia harus menghilangkan penyakit hatinya sendiri yang akan membawanya pada kesulitan hidup dengan cara berdoa, bersedekah, dan lain lain dan hal tersebut tercermin dalam setiap proses Nede. 


\section{Hubungan dengan Keluarga}

Dalam Islam kita dianjurkan untuk berbuat baik kepada keluarga dan kerabat. Akhlak ini sangat dijunjung tinggi oleh masyarakat Sasak yang tinggal di daerah desa Sengkerang khususnya sebagai bentuk ketaatan kepada agama. Akhlak terhadap keluarga, seperti berbuat baik kepada kedua orang tua, saudara, dan kerabat tercermin dari proses Nede. Dalam proses Nede ini juga pada praktiknya dianjurkan untuk mendoakan kedua orang tua, baik yg sudah meninggal atau yang masih hidup. Mendoakan kerabat dan sanak famili, hal inipun adalah bentuk hubungan keharmonisan, kepedulian dan bentuk hubungan baik dengan keluarga.

Kegiatan Nede ini juga merupakan ajang untuk berkumpul bersama keluarga, mulai dari segenap proses praacara seperti mempersiapkan makanan dari rumah tentunya tidak lepas dari kebersamaan. Di Makam Embung Puntiq pun mereka berkumpul bersama keluarga. Hal ini menunjukkan adanya keharmonisan melalui silaturahmi dengan sanak famili sebagai wujud perintah agama Islam untuk menjaga komunikasi dan silaturahmi antarkeluarga baik keluarga jauh maupun dekat.

\section{Hubungan dengan Masyarakat}

Pada praktiknya, Nede tentunya tidak lepas dari hubungan dengan masyarakat. Nede dilakukan secara bersama oleh sesama dan tentunya melewati banyak fase dan proses sebelum dilakukan bahkan pada proses pelaksanaannya. Kegiatan Nede ini tentu pada persiapannya dilakukan musyawarah antarwarga. Tolong menolong pada saat persiapan dan lain sebagainya. Hal tersebut dalam agama Islam memiliki nilai yang tinggi sebagai sebuah akhlak yang harus dijaga. Di bawah ini terdapat anjuran bermusyawarah dalam al-Qur'an.

Dalam prosesi Nede kita diajarkan oleh masyarakat bahwa gotong royong dan mufakat sebagai bentuk hubungan baik dengan masyarakat sebagaimana perintah agama mengharuskan kita untuk menjaga hubungan baik dengan masyarakat sekitar.

Nilai akhlak berupa menjaga hungungan baik dengan masyarakat tecermin dari prosesi yang dilakukan selama ritual Nede, mulai dari persiapan hingga selesai. Proses yang dimulai dari persiapan, masyarakat melakukan musyawarah, dan mufakat mengenai hari dan tanggal akan dilaksanakannya kegiatan merupakan bentuk penjagaan atas hubungan baik dengan sesama manusia baik itu tetangga maupun masyarakat umum. Persaudaraan serta solidaritas merupakan salah satu ciri khas dari masyarakat yang ideal dalam Alquran. Adanya kesamaan ide dan kerja sama mencerminkan masyarakat yang ingin dibangun oleh Islam. Tidak hanya itu, proses pelaksanaan kegiatan Nede ini juga tidak lepas dari nilai-nilai persaudaraan serta kerja sama dalam menyukseskan kegiatan tersebut.

Nilai-nilai akhlak yang terdapat pada ritual ini tentu dapat diambil sebagai pelajaran dalam hidup untuk mencapai hubungan baik dengan masyarakat luas.

\section{Hubungan dengan Lingkungan}

Proses Nede ini juga menampakkan sisi baik pada hubungan manusia dengan lingkungan, manusia haruslah memiliki hubungan baik dengan lingkungan hidup seperti yang diajarkan oleh agama. Pada prosesi adat Nede, terdapat sebuah aturan secara tidak tertulis yang lahir dari kesadaran kelompok untuk menjaga kebersihan selama proses pelaksanaan kegiatan. Mangku akan memberikan imbauan kepada masyarakat yang terlibat dalam prosesi adat untuk tidak meninggalkan sampah atau bekas makanannya. Hal ini tentu tidak akan bisa terjadi apabila tidak didasari oleh kesadaran akan perintah agama untuk menjaga kebersihan. Begitu pentingnya kebersihan sehingga Rasulullah SAW mengingatkan bahwa kebersihan merupakan bagian dari iman. 
Dalam ritual Nede terdapat satu pantangan yang tidak boleh dilakukan yaitu kita dilarang untuk membuang sisa-sisa makanan atau sampah di area sekitar makam. Mangku pada Nede ini menginstruksikan pada segenap warga yang menjalankan ritual ini untuk membersihkan dan tidak menyisakan sampah atau bekas makanan. Makna dari itu adalah menjalankan perintah agama untuk mejaga hubungan baik dengan lingkungan dan alam sekitar.

\section{PENUTUP}

Berdasarkan hasil penelitian terhadap ritual Nede yang ada di Makam Embung Puntiq kecamatan Praya Timur,a dapat ditarik kesimpulan bahwa terdapat nilai religius pada acara ritualnya. Nede sebagai salah satu upacara budaya yang kemudian hadir pada msyarakat Sasak kecamatan Praya Timur sebagai salah satu refleksi dari siklus kehidupan masyarakat suku Sasak. Ritual Nede dilakukan sebagai bentuk rasa syukur, harapan, dan doa masyarakat terhadap Tuhan yang Maha Esa.

Nilai religius dapat ditinjau dari tiga hal yakni akidah, ibadah, dan akhlak. Dalam ritual Nede, keyakinan tentang adanya Allah beserta dengan segala sifat-nya, sangat kental hadir dalam setiap ritual. Hal ini terlihat dari doa-doa yang selalu menghadirkan kalimat tauhid. Ibadah atau ajaran syariat yang terdiri atas lima rukun, yakni syahadat, salat, puasa, zakat, dan ibadah haji, yang tampak pada ritual Nede ialah syahadat. Hal ini karena bentuk-bentuk ritual lebih bercorak sufistik yang penuh makna. Pada tahapan yang terakhir, yakni akhlak, tampak setiap unsur saling memasuki dan hadir dalam setiap ritual. Unsur-unsur akhlak terdiri dari hubungan dengan Allah SWT. Hubungan dengan diri sendiri, hubungan dengan keluarga, hubungan dengan masyarakat, dan hubungan dengan lingkungan.

\section{DAFTAR PUSTAKA}

Ahmadi, Abu dan Noor Salimi. (1994). Dasar-Dasar Pendidikan Agama Islam. Jakarta: Bumi Aksara.

Al Qaradhawi, Yusuf. (1997). Pengantar Kajian Islam. Jakarta: Pustaka Al Kausar.

Asmuni, Yusran. (1997). Dirasah Islamiah 1. Jakarta: Raja Grafindo persada.

Budiwati, Yulia. (2004). Ilmu Budaya Dasar. Jakarta: Universitas Terbuka.

Danandjaya, James. (1986). Folklor Indonesia: Ilmu Gosip, dongeng, dan lain-lain. Graviti.

Daud, Muhammad. (2002). Pendidikan Agama Islam. Jakarta: PT Raja Grafindo Persada.

Endraswara, Suwardi. (2013). Folklor Nusantara: Hakikat, Bentuk, dan Fungsi. Yogyakarta: Penerbit Ombak.

Fadlillah, Muhammad dan Lilif Muallifatul Khorida. (2013). Pendidikan Karakter Anak Usia Dini. Yogyakarta: Ar-Ruzz Media.

Kluckhohn, Clyde. (1953). Universal Categories of Culture. London: University of Chicago Press.

Koentjaraningrat. (2015). Pengantar Ilmu Antropologi. Jakarta: Rineka Cipta.

Muhirdan. (2015). Kuliah Akhlak. Lembaga Pengkajiandan Pegamalan Islam. Universitas Muhammadiyah Mataram.

Nata, Abuddin. (2004). Metodologi Studi Islam. Jakarta: Pt. Raja Grafindo Persada.

Rafiek, M. (2012). Teori Sastra: Kajian Teori dan Praktik. Bandung: Refika Aditama.

Sjarkawi. (2008). Pembentukan Kepribadian Anak. Jakarta: Bumi Aksara.

Sukarta. (2014). Kuliah Akidah. Mataram. Lembaga Pengkajian dan Pengamalan Islam.

Wardani, Rina Yesika Kusuma. (2017). Nilai-Nilai Religius yang Terkandung dalam Tradisi Perkawinan Adat Jawa (Studi Kasus Desa Cerme Kecamatan Pace Kabupaten Nganjuk). Kediri: Universitas Nusantara PGRI Kediri. 
Wulandari, Asri. (2016). Nilai-Nilai Islam yang Terkandung dalam Tradisi Ziarah Kubur pada Hari Raya Idul Fitri Kecamatan Tanjung Batu Kelurahan Tanjung Batu Kabupaten Ogan Ilir. Palembang: Universitas Islam Negri Raden Fatah.

Yuniarti, Dwi Indah Astika. (2013). Nilai-Nilai Religius yang Terkandung dalam Tradisi Temu Manten pada Upacara Perkawinan Adat Jawa (Studi Kasus di Dusun Tanduran Desa Jatisari Kecamatan Jatisrono Kabupaten Wonogiri). Surakarta: Universitas Muhammadiyah Surakarta.

Zuhairini. (1997). Filsafat Pendidikan Islam. Jakarta: Bumi Aksara.

Pahmi, Zul. (2020). Kajian Ikon, Indeks Dan Simbol Dalam Cerita Legenda Lombok Berdasarkan Teori Semiotik. dlm jurnal Dunia Pendidikan, Vol 2. 187-194 